Media Komunikasi dan Informasi Hukum dan Masyarakat

Volume : 19, Nomor : 2

ISSN Online : 2613-9340

ISSN Offline : 1412-1255

\section{Perbuatan Melawan Hukum Dan Menyalahgunakan Wewenang Dalam Tindak Pidana Korupsi}

\section{Indra Gunawan Purba'}

\section{Abstract}

Acts against the law and abuse of authority in a criminal act of corruption are elements that determine whether or not an act can be declared a criminal act. Both of these acts are important to distinguish the boundaries in criminal acts of corruption and also interesting to talk about.There are two legal subjects in a criminal act of corruption, namely a person or every person and corporation as perpetrators and those who can be held liable for criminal acts of corruption committed by their management. Against the law (wederrechtelijk) is one of the elements of a criminal offense in article 2 paragraph (1)of the UUPTPK namely the special unlawful nature. It is referred to as a special unlawful nature because the word against law is explicitly stated in the offense formulation in article 2 paragraph (1) of the UUPTPK. Abusing is defined as the existence of rights or powers that are not carried out properly as it has benefited others, children, grandchildren, family or cronies. There is also misusing the opportunity or time on the perpetrators in connection with the position. Misusing advice means abusing equipment or facilities attached to the perpetrator because of his position.

Key-words : Against the Law, Abuse, authority, Corruption Crime

\section{Abstrak}

Perbuatan melawan hukum dan Penyalahgunaan wewenang dalam tindak pidana korupsi merupakan unsur yang menentukan dapat atau tidaknya suatu perbuatan itu dinyatakan perbuatan pidana. Kedua perbuatan tersebut merupakan hal yang penting untuk dibedakan batasannya dalam tindak pidana korupsi dan juga menarik untuk dibicarakan. Subjek hukum dalam tindak pidana korupsi ada 2 (dua) yaitu orang atau setiap

orang dan korporasi sebagai pelaku dan yang dapat dimintai pertanggungjawaban pidana atas perbuatan korupsi yang dilakukan pengurusnya. Melawan hukum (wederrechtelijk) merupakan salah satu unsur tindak pidana dalam Pasal 2 ayat (1) UUPTPK yaitu sifat melawan hukum khusus. Disebut sebagai sifat melawan hukum khusus karena kata melawan hukum secara eksplisit dicantumkan di dalam rumusan delik di Pasal 2 ayat (1) UUPTPK. Menyalahgunakan diartikan sebagai adanya hak atau kekuasaan yang dilakukan tidak sebagaimana mestinya seperti telah menguntungkan orang lain, anak, cucu, keluarga, atau kroni-kroninya. Menyalahgunakan kesempatan atau waktu pada diri pelaku sehubungan dengan kedudukan atau jabatan. Menyalahgunakan saran berarti menyalahgunakan perlengkapan atau fasilitas yang melekat pada diri pelaku karena jabatan atau kedudukan.

Kata Kunci : Melawan Hukum, Menyalahgunakan, wewenang, Tindak Pidana Korupsi

\section{Pendahuluan}

\section{A. Latar Belakang}

Perbuatan melawan hukum dan penyalahgunaan wewenang dalam tindak pidana korupsi diatur dalam Pasal 2 dan Pasal 3 UU Nomor 31 tahun 1999 sebagaimana telah diubah menjadi UU Nomor 20 tahun 2001 tentang Pemberantasan Tindak Pidana Korupsi (UUPTPK). Ada perbedaan yang mendasar antara kedua perbuatan tersebut, walaupun demikian kedua perbuatan tersebut merupakan unsur yang menentukan dapat atau tidaknya suatu perbuatan itu dinyatakan perbuatan pidana, lebih lanjut kedua perbuatan itu juga penting untuk menentukan seseorang dapat

\footnotetext{
${ }^{1}$ Dosen Universitas Al-Azhar Medan
} 
Media Komunikasi dan Informasi Hukum dan Masyarakat

dipersalahkan melakukan tindak pidana korupsi atau tidak.

Kedua perbuatan itu (melawan hukum dan menyalah gunakan wewenang), merupakan hal yang penting untuk dibedakan batasannya dalam tindak pidana korupsi dan juga menarik untuk untuk dibicarakan. Apalagi kemudian jika dikaitkan dengan subjek hukum tndak pidana Korupsi yaitu : Orang (naturleijk person) dan Korporasi (recht person). Artinya apakah kedua perbuatan itu melawan hukum dan menyalahgunakan wewenang dapat dilakukan oleh kedua subjek hukum ini.

\section{B. Permasalahan}

Berdasarkan latar belakang di atas maka dapat ditarik sebuah permasalahan sebagai berikut:

1. Siapa sajakan subjek hukum tindak pidana Korupsi?

2. Bagaimana Perbuatan Melawan Hukum tindak Pidana Korupsi?

3. Bagaimana Perbuatan Menyalahgunakan Wewenang tidak pidana korupsi?

\section{Metode Penelitian}

Penelitian ini menggunakan jenis penelitian yuridis normatif. Penelitian yuridis normatif dilakukan dengan cara menelaah dan menginpretasikan hal-hal yang bersifat teoritis yang menyangkut asas, konsepsi, doktrin dan norma hukum yang bersangkutan dengan perlindungan hukum terhadap pekerja dalam hal kebebasan berserikat.

Penelitian yuridis normatif adalah pendekatan yang dilakukan berdasarkan bahan hukum utama dengan cara menelah teori-teori, konsep-konsep, asas-asas serta peraturan perundang-undangan yang berhubungan dengan penelitian ini.
Berdasarkan sifatnya maka penelitian bersifat deskriptif bermaksud untuk memberikan gambaran secara jelas dan terprinci mengenai tinjauan.

Dalam penelitian hukum normatif bahan pustaka merupakan dasar yang dalam (ilmu) penelitian digolongkan sebagian data sekunder. Data sekunder dalam penelitian ini dapat dibedakan menjadi 3 bagian :

a. Bahan Hukum Primer dalam penelitian ini adalah bahan hukum yang berkekuatan mengikat yakni Undang-undang Dasar Negara Republik Indonesia, UU Nomor 31 tahun 1999 sebagaimana telah diubah menjadi UU Nomor 20 tahun 2001 tentang Pemberantasan Tindak Pidana Korupsi (UUPTPK).

b. Bahan Hukum Sekunder merupakan bahan yang memberikan penjelasan mengenai bahan hukum primer,seperti rancangan Undang-Undang hasil penelitian dapat berupa pakar hukum serta buku-buku yang berkaitan dengan Pemberantasan Tindak Pidana Korupsi.

a) Bahan Hukum Tersier merupakan yang memberikan penjelasan mengenai bahan hukum primerdan bahan hukum sekunder seperti kamus, ensiklopedia serta artikel dari internet.

Teknik pengumpulan data yang digunakan adalah studi kepustakaan. Studi kepustakaan yang dilakukan oleh peneliti untuk menghimpun informasi dapat diperoleh dari buku-buku ilmiah, penelitian, karangan ilmiah, tesis dan disertai peraturan-peraturan, ketetapanketetapan, buku tahunan, ensiklopedia dan sumber-sumber tertulis baik tercetak maupun elektronik.

Analisis data yang digunakan dalam penelitian ini adalah analisis secara kualitatif 
Media Komunikasi dan Informasi Hukum dan Masyarakat

yaitu uraian yang dilkukan peneliti terhadap data yang terkumpul tidak menggunakan statistik atau matematika ataupun sejenisnya tetapi berupa uraian-uraian kalimat yang tersusun secara sistematis sesuai dengan permaslahan yang dibahas dalam penelitian ini.

Dalam menarik kesimpulan penulis menggunakan metode dedukatif yaitu merupakan cara berfikir yang menarik kesimpulan dari suatu pernyataan atau dalil yang bersifat umum menjadi suatu pernyataan yang bersifat khusus.

\section{PEMBAHASAN}

\section{A. Subjek Hukum Tindak Pidana Korupsi}

\section{Orang (naturlijk person)}

Subjek pelaku tindak pidana korupsi dapat dipahami dari ketentuan Pasal 1 angka 2 UUPTPK dan termasuk juga mereka yang mempunyai tugas, fungsi, dan wewenang sebagai penyelenggara negara sebagaimana ditentukan di dalam UU RI Nomor 28 Tahun 1999. Para pegawai, pengurus, direksi, komisaris pada Bank Pemerintah, Bank BUMN maupun Bank BUMD adalah termasuk sebagai orang yang menerima gaji atau upah dari keuangan negara atau daerah dan juga termasuk penyelenggara negara.

Setiap orang maksudnya adalah subjek yang diduga sebagai pelaku korupsi.Jika diperhatikan subjek korupsi dalam Pasal 1 UUPTPK meliputi setiap orang, pegawai negeri, penyelenggara negara, dan korporasi (badan hukum dan non badan hukum). Maksud setiap orang dalam UUPTPK adalah termasuk siapa saja, baik kedudukannya sebagai pegawai negeri atau penyelenggara negara, akan tetapi unsur setiap orang yang didefenisikan di dalam Pasal 1 angka 3 hanya menentukan untuk orang perseorangan atau korporasi.
Hal ini tentu menjadi masalah dalam undang-undang meskipun faktanya unsur setiap orang juga ditujukan kepada pegawai negeri atau penyelenggara negara.Undangundang sendiri di Pasal 1 angka 3 UUPTPK tidak mengaitkan unsur setiap orang dengan pegawai negeri atau penyelenggara negara, hanya termasuk orang perseorangan atau korporasi. Berdasarkan Pasal 1 angka 3 UUPTPK maka unsur setiap orang yang dimaksud di dalam Pasal 2 ayat (1) UUPTPK tidak menyentuh subjek pegawai negeri, pejabat, dan penyelenggara negara yang ditentukan di dalam Pasal 1 angka 2 UUPTPK.

Mahrus Ali dengan tegas mengatakan unsur setiap orang di Pasal 2 ayat (1) UUPTPK meliputi orang perseorangan atau korporasi, tidak meliputi pegawai negeri atau pejabat atau penyelenggara negara. Jika pegawai negeri atau pejabat atau penyelenggara negara diajukan ke persidangan karena diduga melakukan tindak pidana korupsi, maka Pasal 2 ayat (1) UUPTPK tidak dapat digunakan sebagai dasar untuk mendakwa pegawai negeri atau pejabat atau penyelenggara negara tersebut. $^{2}$

Subjek korupsi di dalam Pasal 2 ayat (1) UUPTPK dimaknai meliputi orang perseorangan atau korporasi pada umumnya, selain pegawai negeri atau pejabat. ${ }^{3}$ Inilah suatu kelemahan aturan tertulis dalam undangundang.Ketentuan ini seolah-olah tidak masalah padahal menjadi masalah yang mendalam. Sangat disayangkan fakta di lapangan yang mengenakan Pasal 2 ayat (1) UUPTPK ini kepada pegawai negeri, atau pejabata, atau penyelenggara negara, padahal tidak relevan dengan Pasal 1 angka 3

\footnotetext{
2 Mahrus Ali, Hukum Pidana Korupsi, UII Press, Yogyakarta, 2016, hal. 84.

3 lbid.
} 
Media Komunikasi dan Informasi Hukum dan Masyarakat

UUPTPK. Seharusnya di Pasal 1 angka 3 UUPTPK dikaitkan dengan Pasal 1 angka 2 UUPTPK.

\section{Korporasi (recht persoon)Sebagai Subjek Hukum Pidana Korupsi.}

Pelaku untuk dapat dimintakan pertanggungjawaban tindak pidana korupsi lebih diperluas lagi cakupannya, yaitu bukan hanya perorangan saja melainkan juga terhadap korporasi. Pasal 1 butir (3) yang menyebutkan bahwa: setiap orang adalah orang perseorangan atau termasuk korporasi.......

Perumusan Pasal 1 butir (3) tersebut, dapat diketahui bahwa subjek atau pelaku tindak pidana korupsi adalah orang perseorangan atau korporasi. Selain itu di dalam Pasal 2 Undang-Undang No. 31 tahun 1999 tentang pemberantasan tindak pidana korupsi jo. Undang-Undang No. 20 tahun 2001 disebutkan bahwa: Dalam hal tindak pidana korupsi sebagaimana dimaksud dalam ayat (1) dilakukan dalam keadaan tertentu, pidana mati dapat dijatuhkan.

Selanjutnya, Pasal 3 menyatakan sebagai berikut: Setiap orang yang dengan tujuan menguntungkan diri sendiri atau orang lain, atau suatu korporasi, menyalahgunakan kewenangan, kesempatan atau sarana yang ada padanya karena jabatan atau kedudukan yang dapat merugikan keuangan negara atau perekonomian negara, dipidana dengan pidana penjara seumur hidup atau pidana penjara paling singkat 1 (satu) tahun dan paling lama 20 (dua puluh) tahun dan atau denda paling sedikit Rp. 50.000.000,00 (lima puluh juta rupiah) dan paling banyak Rp. 1.000.000.000,00 (satu milyar rupiah).

Dari ketentuan tersebut di atas, membuktikan adanya perkembangan baru yang diatur dalam Undang-Undang ini, yaitu diaturnya korporasi sebagai subjek tindak pidana korupsi yang dapat dikenakan sanksi.

Perumusan subjek tindak pidana korupsi sebagaimana diatur dalam Pasal 7 dapat ditafsir bahwa di dalam pengertiannya termasuk korporasi sebagai pelakunya. Adanya kata "pemborong", dapat ditafsirkan sebagai manusia atau juga korporasi, karena pekerjaan yang disebutkan dalam pasal tersebut dapat dilakukan oleh manusia maupun oleh korporasi. Pasal 20 ayat (1) dan (2) yang menyebutkan bahwa:

Ayat (1) : Dalam hal tindak pidana korupsi dilakukan oleh atau atas nama suatu korporasi, maka tuntutan dan penjatuhan pidana dapat dilakukan terhadap korporasi dan atau pengurusnya.

Ayat (2) : Tindak pidana korupsi dilakukan oleh korporasi apabila tindak pidana tersebut dilakukan oleh orang-orang baik berdasarkan hubungan kerja maupun 51 berdasarkan hubungan lain, bertindak dalam lingkungan korporasi tersebut baik sendiri maupun bersama-sama.

Pasal 5 ayat (1) menyebutkan : Dipidana dengan pidana penjara paling singkat 1 (satu) tahun dan paling lama 5 (lima) tahun dan atau pidana denda paling sedikit Rp. 50.000.000,00 (lima puluh juta rupiah) dan paling banyak Rp. 250.000.000,00 (dua ratus lima puluh juta rupiah):

1. Memberi atau menjanjikan sesuatu kepada pegawai negeri atau penyelenggara negara dengan maksud supaya pegawai negeri atau penyelenggara negara tersebut berbuat atau tidak berbuat sesuatu dalam jabatannya, yang bertentangan dengan kewajibannya ;

2. Memberi sesuatu kepada pegawai negeri atau penyelenggara negara karena tau berhubungan dengan sesuatu yang bertentangan kewajiban, dilakukan atau tidak dilakukan dalam jabatannya.

Dipidana dengan pidana penjara paling singkat 3 (tiga) tahun dan paling lama 15 (lima belas) tahun dan dipidana denda paling sedikit $\mathrm{Rp}$. 150.000.000,00 (seratus lima puluh juta rupiah) dan paling banyak Rp. 750.000 .000 (tujuh ratus lima puluh juta rupiah) setiap orang yang: 
1. Memberi atau menjanjikan sesuatu kepada hakim dengan maksud untuk mempengaruhi putusan perkara yang diserahkan kepadanya untuk diadili;

2. Memberi atau menjanjikan sesuatu kepada seseorang yang menurut ketentuan peraturan perundang-undangan ditentukan menjadi advokat untuk menghadiri sidang pengadilan dengan maksud untuk mempengaruhi nasihat atau pendapat yang akan diberikan berhubung dengan perkara yang diserahkan kepada pengadilan untuk diadili.

Pasal 7 menyebutkan : (1) Dipidana dengan pidana penjara paling singkat 2 (dua) tahun dan paling lama 7 (tujuh) tahun dan atau pidana denda paling sedikit Rp. 100.000.000,00 (seratus juta rupiah) dan paling banyak Rp. 350.000.000,00 (tiga ratus lima puluh juta rupiah):

a. Pemborong, ahli bangunan yang pada waktu membuat bangunan, atau penjual bahan bangunan, melakukan perbuatan curang yang dapat membahayakan keamanan orang atau barang, atau keselamatan negara dalam keadaan perang.

b. Setiap orang yang bertugas mengawasi pembangunan atau penyerahan bahan bangunan, sengaja dengan membiarkan perbuatan curang.

c. Setiap orang yang pada waktu menyerahkan barang keperluan Tentara Nasional Indonesia dan atau Kepolisian Negara Republik Indonesia melakukan perbuatan curang yang dapat membahayakan keselamatan negara dalam keadaan perang.

d. Setiap orang yang bertugas mengawasi penyerahan barang keperluan Tentara Nasional Indonesia dan atau Kepolisian Negara Republik Indonesia dengan sengaja membiarkan perbuatan curang.

Pasal 13 menyatakan : Setiap orang yang memberi hadiah atau janji kepada pegawai negeri dengan mengingat kekuasaan atau kewenangan yang melekat pada jabatan atau kedudukannya, atau oleh pemberi hadiah atau janji dianggap melekat pada jabatan atau kedudukan tersebut, dipidana dengan pidana penjara paling lama 3 (tiga) tahun dan atau denda paling banyak Rp. 150.000.000,00 (seratus lima puluh juta rupiah).

Pasal 15 menyatakan : Setiap orang yang melakukan percobaan, pembantuan, atau permufakatan jahat untuk melakukan tindak pidana korupsi, dipidana dengan pidana yang sama sebagaimana dimaksud dengan Pasal 2, Pasal 3, Pasal 5, sampai dengan Pasal 14. Pasal 16 menyatakan : "Setiap orang di luar wilayah negara Republik Indonesia yang memberikan bantuan, kesempatan, sarana, atau keterangan untuk terjadinya tindak pidana korupsi dipidana dengan pidana yang sama sebagai pelaku tindak pidana korupsi sebagaimana dimaksud dengan Pasal 2, Pasal 3, Pasal 5 sampai dengan Pasal 14.

Dengan adanya pengaturan tentang korporasi sebagai subjek tindak pidana korupsi di dalam UU No. 31 Tahun 1999 Jo. UU No. 20 Tahun 2001 tentang pemberantasan tindak pidana korupsi, maka konsekuensinya korporasi dapat dimintai pertanggungjawaban dan dapat dijatuhi pidana atas tindak pidana korupsi yang dilakukannya.

\section{B. Perbuatan Melawan Hukum Tindak Pidana Korupsi}

Tindak pidana korupsi yang mensyaratkan adanya kerugian keuangan negara diatur di dalam Pasal 2 ayat (1) UUPTPK, yang rumusannya sebagai berikut:

Setiap orang yang secara melawan hukum melakukan perbuatan memperkaya diri sendiri atau orang lain atau suatu korporasi yang dapat merugikan keuangan negara atau perekonomian negara, dipidana penjara dengan penjara seumur hidup atau pidana penjara paling singkat 4 (empat) tahun dan paling lama 20 (dua puluh) tahun dan denda paling sedikit Rp.200.000.000,00 (dua ratus juta rupiah) dan paling banyak Rp.1.000.000.000,00 (satu milyar rupiah).

Tindak pidana yang menyaratkan adanya kerugian keuangan negara juga diatur di dalam Pasal 3 UUPTPK, rumusannya sebagai berikut: Setiap orang yang dengan tujuan menguntungkan diri sendiri atau orang lain atau suatu korporasi, menyalahgunakan kewenangan, kesempatan atau sarana yang ada padanya karena jabatan atau kedudukan yang dapat merugikan keuangan negara atau perekonomian negara, dipidana dengan pidana penjara seumur hidup atau pidana penjara 
Media Komunikasi dan Informasi Hukum dan Masyarakat

paling singkat 1 (satu) tahun dan paling lama 20 (dua puluh) tahun dan atau denda paling sedikit Rp.50.000.000,00 (lima puluh juta rupiah) dan paling banyak Rp.1.000.000.000,00 (satu milyar rupiah).

Unsur-unsur tindak pidana (delik)

dalam Pasal 2 ayat (1) UUPTPK tersebut adalah (1) setiap orang, (2) melawan hukum, (3) memperkaya diri sendiri atau orang lain atau suatu korporasi, (4) dapat merugikan keuangan negara atau perekonomian negara. Unsur-unsur tindak pidana (delik) dalam Pasal 3 UUPTPK tersebut adalah (1) setiap orang, (2) tujuan menguntungkan diri sendiri atau orang lain atau suatu korporasi, (3) menyalahgunakan kewenangan, kesempatan atau sarana yang ada padanya karena jabatan atau kedudukan, (4) dapat merugikan keuangan negara atau perekonomian negara. Unsur-unsur tindak pidana korupsi yang terdapat dalam pasalpasal tersebut adalah:

Melawan hukum (wederrechtelijk) menunjukkan sifat yang tidak sah dari suatu tindakan (vide: Pasal 167 ayat 1, Pasal 179, Pasal 180, dan Pasal 190 KUHP), dan sifat tidak sah dari suatu maksud (vide: Pasal 328, Pasal 339, Pasal 362, dan Pasal 389 KUHP). ${ }^{4}$ Melawan hukum merupakan salah satu unsur tindak pidana di dalam Pasal 2 ayat (1) UUPTPK, yaitu sifat melawan hukum khusus.Disebut sebagai sifat melawan hukum khusus karena kata melawan hukum secara eksplisit dicantumkan di dalam rumusan delik di Pasal 2 ayat (1) UUPTPK.

Makna melawan hukum diartikan oleh para ahli hukum dalam makna yang beragam. Melawan hukum menurut Bemmelen adalah perbuatan yang bertentangan dengan ketelitian yang pantas dalam pergaulan masyarakat mengenai orang lain atau barang, dan bertentangan dengan kewajiban yang ditetapkan dalam undang-

${ }^{4}$ P.A.F. Lamintang, Dasar-Dasar Hukum Pidana Indonesia, Sinar Baru, Bandung, 1984, hal. 332. undang. ${ }^{5}$ Melawan hukum menurut Hazewink el-Suringa adalah tanpa hak atau wewenang sendiri, bertentangan dengan hak orang lain, dan bertentangan dengan hukum objektif. ${ }^{6}$

Melawan hukum menurut Van Hattum harus dibatasi hanya pada hukum yang tertulis atau bertentangan dengan hukum tertulis. Melawan hukum menurut Simons sepanjang disebutkan di dalam undang-undang. ${ }^{7}$ Melawan hukum menurut Vos adalah perbuatan yang oleh masyarakat tidak diperbolehkan. ${ }^{8}$ Melawan hukum menurut Enschede termasuk juga didalamnya melawan norma-norma masyarakat. $^{9}$

Sifat melawan hukum dalam hukum pidana memiliki satu frase dengan empat makna, yaitu sifat melawan hukum umum, sifat melawan hukum khusus, sifat melawan hukum formil dan sifat melawan hukum materil.Sifat melawan hukum umum merupakan syarat umum dapat dipidananya suatu perbuatan.Setiap perbuatan pidana didalamnya pasti mengandung unsur melawan hukum.Sifat melawan hukum khusus terkait dengan pencantuman kata melawan hukum secara eksplisit dalam rumusan delik.Sifat melawan hukum merupakan syarat tertulis untuk dapat dipidananya suatu perbuatan.Sifat melawan hukum formil diartikan sebagai bertentangan dengan undang-undang.Sifat melawan hukum materil diartikan sebagai bertentangan dengan norma-norma dan nilai-nilai dalam masyarakat. ${ }^{10}$

Sifat melawan hukum formil apabila suatu perbuatan telah mencocoki semua unsur yang termuat dalam rumusan delik. Jika ada alasan-alasan pembenar, maka alasan-alasan

${ }^{5}$ J.M. van Bemmelen, Hukum Pidana I: Hukum Pidana Material Bagian Umum, Diterjemahkan oleh Hasan Bina Cipta, tanpa tempat, 1984, hal.149.

${ }^{6} /$ bid., hal. 150.

hal. 336 .

${ }^{7}$ Lamintang, Dasar-Dasar Hukum...1984, Op. cit.,

${ }^{8}$ Moeljatno, Asas-Asas Hukum Pidana, Rineka Cipta, Jakarta, 2008, hal. 141

${ }^{9}$ Mahrus Ali, Op. cit., hal. 86.

${ }^{10} \mathrm{lbid}$. 
Media Komunikasi dan Informasi Hukum dan Masyarakat

tersebut harus juga disebutkan dalam undangundang. Melawan hukum sama dengan melawan undang-undang (hukum tertulis). Sikap melawan hukum materil di samping memenuhi syarat-syarat formil, perbuatan itu harus benar-benar dirasakan oleh masyarakat sebagai perbuatan yang tidak patut atau tercela dan telah dilarang oleh hukum. ${ }^{11}$

Unsur-unsur atau elemen-elemen yang harus ada di dalam suatu perbuatan pidana adalah terdapatnya kelakuan dan akibat dari perbuatan, hal atau keadaan-keadaan yang menyertai perbuatan, keadaan tambahan yang memberatkan pidana, dan unsur melawan hukum yang objektif, dan unsur melawan hukum yang subjektif. ${ }^{12}$ Sifat melawan hukum subjektif bergantung pada bagaimana sikap batin si pelaku. Sifat melawan hukum objektif bergantung pada pelaksanaan perbuatan yang dilarang oleh hukum. ${ }^{13}$

Sifat melawan hukum formal dilihat dari dilarangnya suatu perbuatan dalam undangundang, maka pada setiap delik sudah dengan sendirinya terdapat sifat melawan hukum formil, sedangkan sifat melawan hukum materil dilihat dari sikap batinnya pelaku, maka pada setiap delik dianggap ada unsur sifat melawan hukum materil, harus dibuktikan. ${ }^{14}$ Sifat melawan hukum materil di samping memenuhi syarat formil, secara materil perbuatan itu juga benarbenar dirasakan masyarakat sebagai perbuatan yang tidak patut atau tercela dan dilarang oleh hukum. ${ }^{15}$

${ }^{11}$ EY. Kanter \& SR. Sianturi, Asas-asas Hukum Pidana Di Indonesia Dan Penerapanya, Storia Jakarta, Jakarta, 2002, hal. 142.

${ }_{12}$ Moeljatno, Asas-Asas Hukum Pidana, Rineka Cipta, Jakarta, 1993, hal. 63

${ }_{13}$ Moeljatno, Asas-Asas Hukum Pidana, Rineka Cipta, Jakarta, 2009, hal. 69.

${ }^{14}$ E.Y. Kanter \& S.R. Sianturi, Op. Cit., hal. 143148.
Perbuatan yang masuk kategori melawan hukum secara formil yaitu melakukan sesuatu terbatas pada larangan undangundang. ${ }^{16}$ Sedangkan yang dimaksud dengan melawan hukum secara materil adalah melakukan sesuatu yang dilarang dalam undang-undang maupun berdasarkan asas hukum yang tidak tertulis. ${ }^{17}$ Jika dalam suatu pasal secara nyata terdapat unsur melawan hukum, maka penuntut umum harus membuktikannya, jika unsur tersebut tidak terbukti maka putusannya bebas (vrijspraak). Jika unsur melawan hukum tidak secara tegas merupakan unsur dari suatu tindak pidana maka tidak terbuktinya unsur tersebut menyebabkan putusannya lepas dari segala tuntutan hukum (onslag van rechtverfolging) ${ }^{18}$

Kedudukan sifat melawan hukum dalam hukum pidana sangat khas.Umumnya telah terjadi kesamaan pendapat di kalangan para ahli hukum dalam memaknai sifat melawan hukum pidana.Menurut Andi Zainal Abidin sifat melawan hukum merupakan salah satu unsur esensial delik yang dinyatakan dengan tegas atau tidak di dalam suatu pasal undang-undang pidana dan tidak mungkin memidana seseorang yang tidak melawan hukum. ${ }^{19}$ Menurut Roeslan Saleh memidana seseorang yang tidak melawan hukum tidak ada artinya. ${ }^{20}$ Seseorang dapat dikatakan melakukan perbuatan pidana jika perbuatannya tersebut bersifat melawan hukum.

Unsur melawan hukum dalam KUHP adakalnya disebutkan secara tegas dan

${ }^{16} \mathrm{~J} . \mathrm{M} . \quad$ van Bemmelen, diterjemahkan oleh Hasnan, Hukum Pidana I, Hukum pidana bagian material Bagian Umum, Bina Cipta, Jakarta,1984, hal. 102-103.

${ }_{17}^{17}$ P.A.F. Lamintang, Dasar...Op. cit, hal. 184

${ }^{18}$ Ibid., hal. 185

19 A. Zainal Abidin, Hukum Pidana I, Sinar Grafika, Jakarta, 2007, hal. 47.

20 Roeslan Soleh, Sifat Melawan Hukum Dari Perbuatan Pidana, Aksara Baru, Jakarta,1987, hal. 1. 
Media Komunikasi dan Informasi Hukum dan Masyarakat

eksplisit di dalam rumusan delik dan ada kalanya tidak disebutkan.Jika melawan hukum dicantumkan secara tegas dan eksplisit di dalam rumusan delik maka hal itu berarti memberikan perlindungan atau jaminan tidak dipidananya orang yang berhak atau berwenang melakukan perbuatan yang dirumuskan dalam undang-undang. ${ }^{21}$

Penambahan unsur melawan hukum dalam rumusan delik dimaksudkan untuk membatasi ruang lingkup rumusan delik yang dibuat terlalu luas. Hanya jika suatu perilaku yang secar formal dapat dirumuskan dalam ruang lingkup rumusan delik, namun secara umum sebenarnya bukan merupakan perbuatan pidana, maka syarat melawan hukum dijadikan satu bagian dari rumusan delik. $^{22}$

Konsekuensi pencantuman melawan hukum dalam rumusan delik adalah menyebabkan Jaksa Penuntut Umum harus membuktikan unsur tersebut, namun jika unsur "melawan hukum" tersebut tidak dicantumkan secara tegas dan eksplisit dalam rumusan delik, maka unsur melawan hukum tersebut tidak perlu dibuktikan. Unsur melawan hukumnya perbuatan itu secara otomatis telah terbukti dengan telah terbuktinya perbuatan yang dilarang. ${ }^{23}$ Sekalipun unsur "melawan hukum" tidak disebutkan dalam rumusan delik, maka secara diam-diam sifat melawan hukum tersebut telah ada dalam delik tersebut. ${ }^{24}$

Unsur melawan hukum dalam UUPTPK diartikan sebagai melawan hukum formil dan

${ }^{21}$ Tongat, Dasar-Dasar Hukum Pidana Indonesia Dalam Perspektif Pembaharuan, UMM Press, Malang, 2008, hal. 211

22 Chairul Huda, Dari Tiada Pidana Tanpa Kesalahan Menuju Tiada Pertanggungjawaban Pidana Tanpa Kesalahan, Kencana, Jakarta, 2006, hal. 50.

${ }^{23}$ Tongat, Dasar-Dasar Hukum Pidana Indonesia Dalam Perspektif Pembaruan, UMM Press. Malang,2008, hal. 214. melawan hukum materil. Suatu perbuatan dikatakan melawan hukum formil jika perbuatan itu diancam pidana dan dirumuskan sebagai suatu delik dalam undang-undang.Suatu perbuatan dikatakan melawan hukum formil jika perbuatan itu telah mencocoki larangan undang-undang.Suatu perbuatan tidak bisa dianggap melawan hukum jika perbuatan tersebut tidak secara eksplisit dirumuskan dalam undang-undang sebagai perbuatan pidana, sekalipun perbuatan tersebut merugikan masyarakat.Jadi standar untuk menentukan suatu perbuatan melawan hukum atau tidak adalah undang-undang.

Suatu perbuatan disebut sebagai perbuatan pidana (strafbaar feit), maka unsurunsur atau elemen-elemen yang harus ada di dalam suatu perbuatan pidana tersebut harus terdapatnya kelakuan dan akibat dari perbuatan, hal atau keadaan-keadaan yang menyertai perbuatan, keadaan tambahan yang memberatkan pidana, unsur melawan hukum yang objektif, dan unsur melawan hukum yang subjektif. ${ }^{25}$ Istilah perbuatan melawan hukum dalam hukum pidana dikenal dengan istilah wederrechtelijkheid.

Sifat perbuatan melawan hukum dalam hukum pidana secara formil apabila suatu perbuatan telah mencocoki semua unsur yang termuat dalam rumusan delik. Jika ada alasan-alasan pembenar, alasan-alasan tersebut harus juga disebutkan secara tegas dalam undang-undang. Melawan hukum sama dengan melawan undangundang (hukum tertulis). Sikap melawan hukum secara materil di samping memenuhi syarat-syarat formil, perbuatan itu harus benar-benar dirasakan oleh masyarakat sebagai perbuatan yang tidak patut atau tercela dan telah dilarang oleh hukum. ${ }^{26}$

\footnotetext{
${ }^{25}$ Moeljatno, Asas-Asas Hukum Pidana, Rineka Cipta, Jakarta, 1993, hal. 63.

${ }^{26}$ EY. Kanter, \& SR. Sianturi, Op. cit, hal. 142.
} 
Media Komunikasi dan Informasi Hukum dan Masyarakat

Sifat dari perbuatan melawan hukum dibagi dua yakni melawan hukum subjektif dan melawan hukum objektif. Sifat melawan hukum subjektif bergantung pada bagaimana sikap batin si pelaku. Sedangkan sifat melawan hukum objektif bergantung pada pelaksanaan perbuatan yang dilarang oleh hukum. ${ }^{27}$ Sehingga dalam hukum pidana, makna perbuatan melawan hukum juga diperluas, di samping melawan undang-undang (formil), juga melawan asas-asas kepatutan dan kesusilaan dalam masyarakat (materil).

Sifat perbuatan melawan hukum (wederrechtelijkheid) $^{28}$ terdapat dua sifat yaitu bersifat melawan hukum formil dan bersifat melawan hukum materil. Sifat melawan hukum formil dilihat dari dilarangnya suatu perbuatan oleh undang-undang, maka pada setiap delik dengan sendirinya memiliki sifat melawan hukum sedangkan sifat melawan hukum materil dilihat dari sikap batinnya pelaku, maka pada setiap delik dianggap ada unsur sifat melawan hukum, harus dibuktikan. ${ }^{29}$

Unsur melawan hukum menurut M. van Bemmelen dapat memiliki dua pengertian yaitu secara formil dan materil, yang masuk kategori melawan hukum secara formil yaitu melakukan sesuatu terbatas pada yang dilarang oleh undang-undang. ${ }^{30}$ Sedangkan melawan hukum secara materil menurut P.A.F. Lamintang adalah melakukan sesuatu yang dilarang dalam perundang-undangan maupun berdasarkan asas hukum yang tidak tertulis. ${ }^{31}$

Apabila dalam suatu pasal secara nyata terdapat unsur melawan hukum, maka penuntut umum harus membuktikan unsur

\footnotetext{
27 Moeljatno, Asas-Asas Hukum Pidana, Rineka Cipta, Jakarta, 2009, hal. 69.

28 E.Y. Kanter dan S.R. Sianturi, Op. Cit., halaman 143-144.

${ }^{29}$ Ibid., hal. 147-148.

${ }^{30}$ J.M. van Bemmelen, Op. cit, hal. 102-103.

31 P.A.F. Lamintang, Dasar...Op. cit, hal. 184.
}

tersebut, jika unsur tersebut tidak terbukti maka putusannya vrijspraak atau putusan bebas. Sedangkan, jika unsur melawan hukum tidak secara tegas merupakan unsur dari suatu tindak pidana maka tidak terbuktinya unsur tersebut menyebabkan putusannya lepas dari segala tuntutan hukum (onslag van rechtverfolging). ${ }^{32}$

Selain karena melawan hukum, unsur yang kedua, yaitu unsur kesalahan (schuld). Adagium mengatakan, geen straf zonder schuld (tiada hukuman tanpa kesalahan), ini berarti orang yang dihukum harus terbukti bersalah secara pidana. Kesalahan mengandung dua pengertian, dalam arti sempit yang berarti kesengajaan (dolus/opzet) yang berarti berbuat dengan kehendak dan maksud atau dengan menghendaki dan mengetahui (willen en wetens), sedangkan dalam arti luas berarti dolus dan culpa. ${ }^{33}$

Kelalaian atau kealpaan (culpa) bilamana pada diri pelaku terdapat kekurangan pemikiran, kekurangan pengetahuan, dan unsur yang ketiga yaitu pertanggungjawaban subjek. Sesuatu dapat dikatakan sebagai tindak pidana apabila ada subjek (pelaku) dari tindak pidana itu sendiri. Agar pelaku itu dapat dipidana, maka dalam diri pelaku secara subjek tidak terdapat dasar penghapus pidana, baik dasar pembenar maupun dasar pemaaf. kekurangan kebijaksanaan yang diperlukan. ${ }^{34}$

Memperkaya harus dikaitkan dengan kewajiban terdakwa untuk memberikan keterangan tentang sumber kakayaan tersebut sehingga kekayaan yang tidak seimbang

\footnotetext{
${ }^{32}$ Ibid., hal. 185.

33 Jan Remmelink, Hukum Pidana, Komentar Atas Pasal-Pasal Terpenting dari Kitab Undang-Undang Hukum Pidana Belanda dan Padanannya Dalam Kitab Undang-Undang Hukum Pidana Indonesia, Gramedia Pustaka Utama, Jakarta, 2003, hal. 173.

${ }^{34}$ SR. Sianturi, Tindak Pidana di KUH Pidana, Alumni AHM-PTHM, Jakarta,1983, hal. 92.
} 
Media Komunikasi dan Informasi Hukum dan Masyarakat

dengan penghasilannya sebagai alasan untuk memperkuat keterangan saksi dan bukti-bukti lainnya bahwa pelaku telah melakukan tindak pidana korupsi. ${ }^{35}$ Penafsiran istilah memperkaya antara makna harfiah dan pembuat undang-undang hampir sama, keduanya menunjukkan perubahan kekayaan atau bertambahnya kekayaan dikukur dari penghasilan yang diperolehnya. ${ }^{36}$

Makna memperkaya orang lain merupakan sebagai akibat dari perbuatan melawan hukum pelaku dan orang lain yang menikmati bertambahnya harta bendanya. ${ }^{37}$ Bertambahnya kekayaan bukan hanya pelaku langsung, tapi juga bertambahnya kekayaan sebagai akibat dari perbuatan melawan hukum tersebut termasuk orang lain atau suatu korporasi, yaitu kumpulan orang atau kumpulan kekayaan yang terorganisasi, berupa badan hukum maupun non badan hukum.

Makna memperkaya tidak ada keharusan hanya pelaku saja yang bertambah kekayaannya dari akibat melakukan tindak pidana korupsi, tapi juga orang lain, atau suatu badan hukum maupun non badan hukum dan hal itu harus ada kaitannya dengan berkurangnya kekayaan negara.Tindak pidana korupsi menjadi penyebab bertambahnya kekayaan pelaku, orang lain, atau suatu korporasi dan sekaligus menjadi penyebab terjadinya kerugian keuangan negara atau perekonomian negara.

Dapat merugikan keuangan negara atau perekonomian negara. Konsep kerugian negara yang dimaksud dalam pengertian ini tidak sama dengan pengertian kerugian dalam

\footnotetext{
${ }^{35}$ Mahrus Ali, Op. cit., hal. 85.

${ }^{36}$ Andi Hamzah, Pemberantasan Korupsi Melalui Hukum Pidana Nasional dan Internasional, RajaGrafindo Persada, Jakarta, 2004, hal. 174-175.

37 Darwin Prints, Pemberantasan Tindak Pidana Korupsi, Citra Adtya Bakti, Bandung,2002, hal. 31.
}

dunia perusahaan atau perniagaan, melainkan suatu kerugian negara yang terjadi karena sebab perbuatan melawan hukum atau penyalahgunaan wewenang. Terjadinya kerugian negara disebabkan karena dilakukannya perbuatan yang dilarang dalam hukum pidana, baik dilakukan oleh orang perseorangan, korporasi, maupun oleh subjek hukum yang spesifik yaitu pegawai negeri atau pejabat atau penyelenggara negara. ${ }^{38}$

Delik disebut juga dengan tindak pidana yang dirumuskan dalam undangundang. Delik dibedakan menjadi dua berdasarkan cara perumusannya, yaitu delik formil dan delik materil. Pada intinya delik formil tidak diperlukan adanya akibat, dengan terjadinya tindak pidana sudah dinyatakan tindak pidana tersebut telah terjadi dan dapat dipidana.Berbeda dengan delik materil, tindak pidana dinyatakan terjadi jika telah ada akibatnya, baru dapat dipidana. ${ }^{39}$

Merugikan keuangan negara atau perekonomian negara merupakan salah satu unsur tindak pidana korupsi. ${ }^{40}$ Unsur "dapat merugikan keuangan negara" merupakan delik formil, sehingga perbuatan yang berpotensi merugikan keuangan negara dapat dipidana.Tidak harus dengan timbulnya akibat.Selama bukti-bukti kuat mengarah pada potensi kerugian negara maka berdasarkan delik formil dapat dipidana. ${ }^{41}$

Delik formil yaitu perbuatannya nyata dilaksanakan walaupun tidak terjadi suatu akibat yaitu kerugian keuangan negara dapat dipidana.Delik materil yang diutamankan bukan pada unsur-unsur yang harus dipenuhi dalam ketentuan hukum formil tetapi lebih kepada

\footnotetext{
${ }^{38}$ Mahrus Ali, Op. cit., hal. 91.

${ }^{39}$ EY. Kanter \& SR. Sianturi, OP. Cit., hal. 237.

${ }^{40}$ Jamin Ginting, Op. cit., hal. 29.

${ }^{41}$ Ibid., hal. 35.
} 
Media Komunikasi dan Informasi Hukum dan Masyarakat

perbuatan yang nyata (akibat) sudah dapat dipidana. ${ }^{42}$

Pasal 2 ayat (1) UUPTPK cukup jelas menentukan konsep kerugian negara dalam arti delik formil dalam rumusannya dapat merugikan keuangan negara atau perekonomian negara. Kata dapat sebelum frasa merugikan keuangan atau perekonomian negara" dalam penjelasan pasal ini menunjukkan bahwa tindak pidana korupsi dalam Pasal 2 ayat (1) merupakan delik formil, yaitu adanya tindak pidana korupsi cukup dengan dipenuhinya unsur-unsur perbuatan yang sudah dirumuskan bukan dengan timbulnya akibat. ${ }^{43}$

Permasalahan timbul dari kata dapat sebelum kalimat "merugikan keuangan negara" adalah ketidakpastian hukum.Tidak mungkin hukum memberi sanksi pidana pada aturan yang belum jelas atau belum tentu peristiwanya terjadi dapat dihukum, penafsiran kata dapat juga tergantung bagi siapa saja yang menafsirkannya. Hal ini tentu akan memberikan keguncangan bagi masyarakat. Membuat kalimat samarsamar dalam undang-undang akan dapat memberikan kewenangan kepada setiap pejabat yang melaksanakan undang-undang tersebut secara tanpa batas sehingga dapat menimbulkan apa yang disebut judicial dictatorship. ${ }^{44}$

Terlepas dari kemungkinan terjadinya kerugian negara, pertanyaan yang mengusik adalah apakah kerugian negara itu harus dalam bentuk nyata dan pasti jumlahnya, ataukah potensi terjadinya kerugian keuangan negara (potential lose) sudah bisa dianggap sebagai kerugian negara? Pertanyaa ini dikemukakan

\footnotetext{
${ }^{42}$ Ibid., hal. 36 .

${ }^{43}$ Ibid.

44 Erman Rajagukguk, "Pengertian Keuangan Negara dan Kerugian Negara", Makalah yang Disampaikan pada Seminar Pengertian, Keuangan Negara Dalam Tindak Pidana Korupsi, Tanggal 26 Juli, Jakarta,2006, hal. 10.
}

mengingat hingga kini belum ada kesamaan pendapat mengenai hal tersebut.

Ahli hukum pidana pada umumnya mengatakan potensi kerugian keuangan negara sudah dapat dikategorikan telah terjadi kerugian keuangan negara. Kata dapat sebelum frase merugikan keuangan negara atau perekonomian negara menunjukkan bahwa tindak pidana korupsi merupakan delik formil, yaitu adanya tindak pidana korupsi cukup dengan dipenuhinya unsur-unsur perbuatan yang sudah dirumuskan bukan dengan timbulnya akibat. Kerugian negara atau perekonomian negara tidak perlu sudah terjadi, akan tetapi cukup dengan dipenuhinya unsurunsur dari perbuatan yang dirumuskan telah terlaksana atau selesai dilakukan. ${ }^{45}$

Menurut Adami Chazawi kerugian keuangan negara atau perekonomian negara bukanlah menjadi syarat untuk terjadinya tindak pidana korupsi di Pasal 2 ayat (1) UUPTPK secara sempurna, melainkan akibat kerugian keuangan negara dapat timbul dari perbuatan memperkaya diri dengan melawan hukum. ${ }^{46}$ Pandangan ini penganut delik formil terhadap Pasal 2 ayat (1) UUPTPK. Cukup dengan dipenuhinya unsur-unsur perbuatan yang sudah dirumuskan bukan dengan timbulnya akibat.

Sebahagian ahli hukum ada juga yang berpandangan bahwa Pasal 2 ayat (1) UUPTPK mengandung delik materil. Kata dapat sebelum frase merugikan keuangan negara atau perekonomian negara memang menunjukkan bahwa delik ini merupakan delik formil, yaitu suatu delik yang hanya memfokuskan pada perbuatan tertentu yang

\footnotetext{
${ }^{45}$ Mahrus Ali, Op. cit., hal. 93.

46 Adami Chazawi, Hukum Pidana Materil dan Formil Korupsi di Indonesia, Bayumedia Publishing, Malang,2005, hal. 45 .
} 
Media Komunikasi dan Informasi Hukum dan Masyarakat

dilarang, bukan pada akibat dari perbuatan itu.

Akan tetapi jika delik ini dimaknai sebagai delik formil maka ketentuan dalam Pasal 2 ayat (1) UUPTPK jelas bertentangan dengan unsurunsur lain dalam pasal tersebut, yaitu unsur memperkaya diri sendiri, orang lain, atau suatu korporasi. ${ }^{47}$

Unsur di dalam Pasal 2 ayat (1) UUPTPK menyaratkan bertambahnya kekayaan diri sendiri, orang lain, atau suatu korporasi, dari yang tidak ada menjadi ada, dari yang sudah ada menjadi bertambah ada atau menjadi lebih kaya.Adanya penambahan kekayaan pada mereka di satu sisi, sedangkan di sisi lain, keuangan negara atau perekonomian negara telah mengalami kerugian sehingga dengan sendirinya merugikan keuangan negara atau perekonomian negara secara materil harus ada dan mutlak harus dibuktikan, tidak cukup dengan berpotensi semata. ${ }^{48}$

Pasal 1 angka 22 UU RI Nomor 1 Tahun 2004 Tentang Perbendaharaan Negara, menentukan definisi kerugian negara/daerah adalah "kekurangan uang, surat berharga, dan barang, yang nyata dan pasti jumlahnya sebagai akibat perbuatan melawan hukum baik sengaja maupun lalai. Pasal ini harus menjadi acuan memahami makna kerugian negara karena memberikan kepastian hukum bahwa kerugian negara harus nyata dan pasti jumlahnya dan bukan sesuatu yang dapat merugikan keuangan negara. Ini berarti potensi saja tidak cukup untuk menyatakan bahwa telah terjadi kerugian keuangan negara,

${ }^{47}$ Nur Basuki Minarmo, Penyalahgunaan Wewenang dan Tindak Pidana Korupsi Dalam Pengelolaan Keuangan Daerah, Leksbang Mediatama, Yogyakarta 2009, hal. 50. melainkan kerugian negara tersebut harus nyata terjadi dan pasti jumlahnya. ${ }^{49}$

Alasan yang cukup menarik jika kata "dapat" diartikan sebagai potential lose adalah sangat berbahaya. Bisa saja para pegawai, pengurus, direksi, komisaris pada Bank Pemerintah (Bank BUMN maupun Bank BUMD) tidak berani menyalurkan kredit kepada masyarakat khususnya debitur pemohon, pejabat atau pegawai negeri maupun penyelenggara negara tidak berani ditunjuk sebagai panitia pengadaan barang dan/atau jasa, karena tindakan mereka yang berpotensi merugikan keuangan negara meskipun sangat kecil kemungkinannya dapat dipidana. Bilamana hal semacam ini dipahami dalam Pasal 2 ayat (1) UUPTPK maka roda pemerintahan tentu akan mengalami stagnasi (kemadekan). ${ }^{50}$

Unsur dari kalimat dapat merugikan keuangan negara tidak menimbulkan kepastian hukum, karena kerugian belum nyata, belum tentu terjadi dan tidak diketahui jumlah kerugian negara yang dirugikan.Berdasarkan asas kepastian hukum maka delik formil dari UUPTPK yang menyebutkan "dapat merugikan keuangan negara seharusnya dicabut. ${ }^{51}$ Kepastian hukum yang dimaksud adalah kepastian hukum yang ditentukan di dalam undang-undang.

Putusan MK Nomor 003/PUU-IV/2006 Tanggal 24 Juli 2006 memutuskan bahwa kata "dapat" dalam Pasal 2 ayat (1) UUPTPK tidak bertentangan dengan Pasal 28 D ayat (1) UUD Tahun 1945 sepanjang ditafsirkan bahwa unsur kerugian negara harus dibuktikan dan harus dapat dihitung. Sehingga persoalan kata dapat di Pasal 2 ayat (1) UUPTPK lebih merupakan

\footnotetext{
${ }^{49}$ Mahrus Ali, Op. cit., hal. 94.

${ }^{50}$ lbid.

51 Jaimin Ginting, Op. cit., hal. 37.
} 
Media Komunikasi dan Informasi Hukum dan Masyarakat

persoalan pelaksanaan dalam praktik oleh aparat penegak hukum, bukan menyangkut konstitusionalitas norma. Putusan MK ini menyatakan penjelasan Pasal 2 ayat (1) UUPTPK tidak berlaku karena bertentangan dengan UUD Tahun 1945.

Penjelasan Pasal 2 ayat (1) UUPTPK yang dinyatakan tidak berlaku dan bertentangan dengan UUD Tahun 1945 tersebut adalah Yang dimaksud dengan secara melawan hukum dalam pasal ini mencakup perbuatan malawan hukum dalam arti formil maupun dalam arti materiil, yakni meskipun perbuatan tersebut tidak diatur dalam peraturan perundang-udangan, namun apabila perbuatan tersebut dianggap tercela karena tidak sesuai dengan rasa keadilan atau norma-norma kehidupan sosial dalam masyarakat, maka perbuatan terebut dapat dipidana".

MK berpendapat kata dapat sebelum frase merugikan keuangan Negara terdapat dua hubungan yang estrim, yaitu: (1) nyata-nyata merugikan negara atau (2) kemungkinan dapat menimbulkan kerugian negara. Kemungkinan dapat menimbulkan kerugian negara inilah lebih dekat dengan maksud mengkualifiikasikan delik korupsi menjadi delik formil.Di antara dua hubungan tersebut sebenarnya masih ada hubungan yang belum nyata terjadi, tetapi dengan mempertimbangkan keadaan khusus dan konkrit di sekitar peristiwa. ${ }^{52}$

Untuk mempertimbangkan keadaan khusus dan konkrit di sekitar peristiwa yang terjadi yang secara logis dapat disimpulkan bahwa kerugian negara terjadi atau tidak terjadi haruslah dilakukan oleh ahli dalam keuangan negara, perekonomian negara serta ahli dalam analisis hubungan perbuatan seseorang dengan kerugian.MK juga berpendapat bahwa unsur kerugian negara haruslah dibuktikan dan harus dapat dihitung, meskipun sebagai perkiraan atau meskipun belum terjadi dan harus ditentukan oleh seorang ahli dibidangnya..$^{53}$

Menurut MK delik materil dalam penjelasan Pasal 2 ayat (1) UUPTPK tidak sesuai dengan kepastian hukum, sehingga unsur adanya kerugian keuangan negara harus dibuktikan dengan delik formil berdasarkan unsur-unsur yang terdapat dalam peraturan perundang-undangan dan bukan delik materil yang merujuk pada hukum tidak tertulis dalam ukuran kepatutan, kehati-hatian dan kecermatan yang hidup dalam masyarakat sebagai suatu norma keadilan.

Menurut MK penggunaan hukum materil dalam tindak pidana korupsi merupakan ukuran yang tidak pasti dan bertentangan dengan asas "nullum delictum noela poena sine praevia lege poenall' yaitu tiada suatu perbuatan dapat dipidana kecuali berdasarkan kekuatan ketentuan undang-undang pidana yang telah ada sebelumnya. Dalam praktik penegakan hukum, timbulnya akibat yaitu kerugian keuangan negara pada BUMN, meskipun tidak dipenuhi rumusan delik formilnya, tetap saja seseorang itu dijatuhkan pidana (vide: kebijakan publik yang merugikan keuangan negara sering kali dipaksakan masuk ke ranah delik korupsi).

Putusan MK ini dipandang sudah tepat untuk mencabut kata "dapat" sebelum frase "merugikan keuangan negara" dicabut sehingga memberikan kepastian hukum, tetapi dalam praktik akan terjadi kekosongan karena pencabutan Pasal 2 ayat 1 UUPTPK tersebut. Oleh sebab itu pedoman untuk menentikan merugikan keuangan negara harus mengacu pada ketentuan Pasal 1 angka 22 UU RI Nomor 1 
Media Komunikasi dan Informasi Hukum dan Masyarakat

Tahun 2004 Tentang Perbendaharaan Negara. ${ }^{54}$

Bilamana rumusan dalam UUPTPK menganut arti delik formil, UU RI Nomor 1 Tahun 2004 Tentang Perbendaharaan Negara menganut delik materil, maka dengan demikian jika secara materil perbuatan itu nyata dilakukan walaupun tidak ada kerugian keuangan negara dapat dipidana. Dengan demikian perbuatan materil yang diutamankan bukan berdasarkan unsur-unsur yang harus dipenuhi dalam ketentuan hukum formil tetapi lebih kepada perbuatan yang nyata sudah dapat dipidana.

Pasal 2 ayat (1) UUPTPK mengandung konsep kerugian negara dalam arti delik formil dalam rumusan dapat merugikan keuangan negara atau perekonomian negara. Penjelasan pasal tersebut juga mengatakan kata "dapat" sebelum frasa merugikan keuangan atau perekonomian negara menunjukkan bahwa tindak pidana korupsi merupakan delik formil, yaitu adanya tindak pidana korupsi cukup dengan dipenuhinya unsur-unsur perbuatan yang sudah dirumuskan bukan dengan timbulnya akibat.

Unsur tujuan menguntungkan diri sendiri atau orang lain atau suatu korporasi merupakan alternatif. Apabila perbuatan yang dilakukan oleh terdakwa telah dilakukan dengan tujuan untuk menguntungkan salah satu unsur tersebut, maka dengan sendirinya unsur ini telah terpenuhi.Jika tidak terbukti unsur tersebut maka harus seluruh unsur tersebut tidak terbukti. Misalnya jika hanya yang terbukti adalah menguntungkan diri sendiri maka unsur ini telah terbukti meskipun unsur menguntungkan orang lain atau korporasi tidak terbukti.
Unsur tujuan menguntungkan diri sendiri atau orang lain atau suatu korporasi lebih mudah dipamahi dari aspek pembuktian. Unsur menguntungkan tidak memerlukan dimensi apakah terdakwa tindak pidana korupsi menjadi kaya atau bertambah kaya atau bertambah kaya karenanya. ${ }^{55}$ Oleh karena itu cukup diperolehnya keuntungan, sudah dapat dikategorikan memenuhi unsur ini.

Kata menguntungkan secara etimologi memiliki arti sebagai mendapatkan keuntungan sehingga pendapatan yang diperolehnya lebih besar dibandingkan dengan pengeluaran. ${ }^{56}$

Berarti menguntungkan diri sendiri atau orang lain atau suatu korporasi sama artinya dengan mendapatkan keuntungan untuk dirinya sendiri atau orang lain atau suatu korporasi. ${ }^{57}$

Seseorang atau orang lain atau suatu korporasi tidak harus mendapatkan banyak uang, namun cukup apabila dengan mendapatkan sejumlah uang yang dari uang tersebut seseorang atau orang lain atau korporasi akan memperoleh keuntungan daripadanya walaupun sedikit. Memperoleh suatu keuntungan atau menguntungkan artinya memperoleh atau menambah kekayaan dari yang sudah ada. ${ }^{58}$

Unsur menguntungkan diri sendiri atau orang lain atau suatu korporasi merupakan tujuan dari pelaku tindak pidana. ${ }^{59}$ Jika menguntungkan diri sendiri atau orang lain atau suatu korporasi merupakan tujuan dari pelaku tindak pidana, maka tidak berlaku bagi seorang terdakwa yang tidak mempunyai tujuan menguntungkan diri sendiri atau orang lain atau suatu korporasi. Dalam kontek ini maka unsur ini tidak terpenuhi. Namun dalam dakwaannya dimasukkan Pasal 55 ayat (1) ke-1 KUHP,

55 Lilik Mulyadi, Tindak Pidana Korupsi...2007, Op. cit., hal. 91.

${ }^{56}$ Ermansjah Djaja, Op. cit., hal. 159.

${ }^{57}$ Ibid.

${ }^{58}$ P.A.F. Lamintang, Delik...Op. cit, hal. 276.

cit. 
Media Komunikasi dan Informasi Hukum dan Masyarakat

maka berpotensi terdakwa tersebut dikenakan tindak pidana korupsi secara bersama-sama, karena Pasal 55 ayat (1) ke-1 KUHP tidak memerlukan adanya rencana atau niat dari masing-masing peserta.

Hal inilah yang membedakan kata menguntungkan dengan kata memperkaya. Unsur memperkaya lebih sulit untuk membuktikannya karena tidak ada ambang batas kekayaan yang didefenisikan oleh undang-undang, sehingga ambang batas minimal unsur memperkaya diri sendiri, orang lain atau korporasi, hakim mempedomani Hasil Rumusan Rapat Kamar Pidana MA minimal Rp.100.000.000,- (seratus juta rupiah).

Kata memperkaya adalah menjadikan orang yang belum kaya menjadi kaya atau orang yang sudah kaya bertambah kaya, mempunyai harta yang banyak atau banyak harta.Memperkaya berarti sebagai perbuatan menjadikannya bertambah kekayaan. Memperkaya diri sendiri atau orang lain adalah menjadikan diri sendiri atau orang lain atau suatu koporasi, yang belum kaya menjadi bertambah banyak hartanya atau orang yang sudah kaya bertambah kekayaannya secara signifikan.

Perbedaan memperkaya dengan menguntungkan adalah seseorang tidak harus mendapatkan banyak uang, namun cukup apabila dengan mendapatkan sejumlah uang sehingga dari uang tersebut seseorang itu telah dikatakan memperoleh keuntungan meskipun sedikit.Sedangkan memperkaya sebagai suatu perbuatan yang menyebabkan perubahan bertambahnya kekayaan seseorang secara banyak, diukur dari penghasilan yang diperolehnya. ${ }^{60}$
Unsur memperkay dalam Pasal 2 ayat (1) UUPTPK dan unsur tujuan menguntungkan dalam Pasal 3 UUPTPK pada prinsipnya mempunyai pengertian yang sama (identik) yaitu masing-masing dirumuskan secara materil. Bertambahnya keuntungan atau kekayaan harus benar-benar terjadi atau secara materil kekayaan dari pejabat atau pegawai negeri, orang lain, atau suatu korporasi itu menjadi bertambah. ${ }^{61}$

\section{Penyalahgunaan Wewenang Dalam Tindak Pidana Korupsi}

Letak perbedaan antara menguntungkan dan memperkaya terletak pada rumusan unsur sebelumnya. Unsur menguntungkan dalam Pasal 3 UUPTPK sebagai akibat dari adanya penyalahgunaan wewenang dalam tindak pidana tersebut, sedangkan unsur memperkaya dalam Pasal 2 ayat (1) UUPTPK sebagai akibat dari perbuatan melawan hukum. Jadi untuk Pasal 3 UUPTPK harus terpenuhi unsur penyalahgunaan wewenang.Sedangkan untuk Pasal 2 ayat (1) harus terpenuhi unsur melawan hukum, barulah dapat dikatakan telah terjadi kerugian keuangan negara.

Manakala unsur penyalahgunaan wewenang dalam Pasal 3 UUPTPK tidak terbukti maka dengan sendirinya unsur dengan tujuan menguntungkan...., tidak perlu dibuktikan. Demikian pula jika unsur perbuatan melawan hukum dalam Pasal 2 ayat (1) UUPTPK tidak terbukti maka dengan sendirinya unsur memperkaya..., tidak perlu dibuktikan. Kecuali Pasal 2 ayat (1) UUPTPK atau Pasal 3 UUPTPK di-junto-kan dengan Pasal 55 ayat (1) ke01 KUHP, maka terdakwa berpotensi 
Media Komunikasi dan Informasi Hukum dan Masyarakat

dipidana dengan perbuatan korupsi secara bersama-sama.

Hal ini tentu akan berdampak pada unsur selanjutnya yaitu unsur dapat merugikan keuangan negara. Jika tetap dipaksakan untuk membuktikan unsur tujuan menguntungkan namun unsur penyalahgunaan wewenang tidak terbukti, maka tidak tepat disebut telah terjadi kerugian keuangan negara. Jika tetap dipaksakan untuk membuktikan unsur memperkaya, tapi unsur melawan hukumnya tidak terbukti, juga tidak tepat disebut telah terjadi kerugian keuangan negara, melainkan hal itu menjadi kerugian bisnis sebagai suatu risiko usaha.

Penambahan kekayaan seseorang tidak perlu harus terwujud dari perbuatan penyalahgunaan wewenang, kesempatan atau sarana yang ada padanya karena jabatan atau kedudukan karena penambahan kekayaan memiliki hubungan erat dengan unsur tujuan menguntungka. Akan tetapi penambahan kekayaan seseorang harus terwujud perbuatan melawan hukum.

Menguntungkan diri sendiri berarti seseorang itu tidak harus mendapatkan banyak uang, tapi cukup dengan mendapatkan sejumlah uang meskipun sedikit. Menguntungkan orang lain berarti orang lain tersebut tidak harus mendapatkan banyak uang, tapi cukup dengan mendapatkan sejumlah uang meskipun sedikit. Menguntungkan suatu korporasi berarti korporasi itu tidak harus mendapatkan banyak uang, namun cukup apabila dengan mendapatkan sejumlah uang meskipun sedikit.

Dampak dari tindak pidana yang dilakukan oleh terdakwa telah menguntungkan dirinya sendiri, atau orang lain, atau korporasi, sehingga dari diperolehnya uang tersebut kemudian seseorang, atau orang lain, atau korporasi tersebut telah dikatakan memperoleh keuntungan meskipun sedikit.Jika salah satu unsur ini terpenuhi maka dapat dikatakan bahwa perbuatan terdakwa telah memenuhi unsur tersebut.

Masalahnya yang kemudian muncul adalah mengenai tafsir keuntungan tersebut.Apakah keuntungan itu termasuk keuntungan berupa uang atau keuntungan bukan berupa uang (benda) atau duaduanya.Hal ini juga tidak ditegaskan dalam undang-undang.Dalam praktik pengadilan kata menguntungkan pada umumnya ditafsirkan dengan keuntungan kedua-duanya. Artinya jika perbuatan terdakwa tersebut telah menimbulkan kesempatan bagi orang lain untuk memperoleh keuntungan riil, maka terdakwa tersebut juga dapat dijatuhkan tindak pidana yaitu tindak pidana korupsi secara bersama-sama.

Praktik pengadilan yang demikian pada prinsipnya dapat dibenarkan secara hukum karena terdakwa yang tidak menyadari bahwa perbuatannya menimbulkan kemungkinankemungkinan, misalnya menguntungkan orang lain sehingga permohonan kredit debitur menjadi mulus. Tafsir "menguntungkan" harus mencakup keuntungan riil berupa uang (benda) maupun keuntungan non riil, misalnya terbukanya kesempatan bagi orang lain atau korporasi.

Unsur menyalahgunakan kewenangan, kesempatan atau sarana yang ada padanya karena jabatan atau kedudukan.Terminologi menyalahgunakan sangat luas cakupan pengertiannya sebagaimana ketentuan Pasal 52 KUHP. Menyalahgunakan diartikan dalam konteks hukum pidana adanya hak atau kekuasaan yang dilakukan tidak sebagaimana 
Media Komunikasi dan Informasi Hukum dan Masyarakat

mestinya seperti telah menguntungkan orang lain, anak, cucu, keluarga, atau kroni-kroninya. Menyalahgunakan kesempatan atau waktu pada diri pelaku sehubungan dengan kedudukan atau jabatan.Menyalahgunakan saran berarti menyalahgunakan perlengkapan atau fasilitas yang ada melekat pada diri pelaku karena jabatan atau kedudukan. ${ }^{62}$

Penyalahgunaan kewenangan pada prinsipnya merupakan wilayahnya hukum administrasi negara yang tidak bisa dipidanakan melainkan pelanggaran administrasi.Unsur menyalahgunakan kewenangan, kesempatan atau sarana yang ada padanya karena jabatan atau kedudukan ternyata dapat ditemukan di dalam Pasal 3 UUPTPK. Unsur ini dikenal dalam hukum pidana korupsi yaitu unsur menyalahgunakan kewenangan, kesempatan atau sarana yang ada padanya karena jabatan atau kedudukan.

Apa yang membedakan unsur menyalahgunakan kewenangan, kesempatan atau sarana yang ada padanya karena jabatan atau kedudukan dapat dipidana dibandingkan dengan penyalahgunaan wewenang dalam hukum administrasi hanya merupakan pelanggaran administrasi. Ternyata jika diperhatikan rumusan Pasla 3 UUPTPK, unsur menyalahgunakan kewenangan, kesempatan atau sarana yang ada padanya karena jabatan atau kedudukan, tidaklah berdiri sendiri, tapi ada kaitannya dengan sifat dan perilaku koruptif yakni adanya unsur tujuan menguntungkan diri sendiri atau orang lain atau suatu korporasi.

Setiap orang yang dengan tujuan menguntungkan diri sendiri atau orang lain atau suatu korporasi, menyalahgunakan kewenangan, kesempatan atau sarana yang ada cit., hal. 93. padanya karena jabatan atau kedudukan yang dapat merugikan keuangan negara atau perekonomian negara, dipidana dengan pidana.... ${ }^{63}$

Berdasarkan rumusan dalam Pasal 3 UUPTK tersebut, dapat diperhatikan rumusan sebelum unsur menyalahgunakan kewenangan, kesempatan atau sarana yang ada padanya karena jabatan atau kedudukan, yaitu unsur tujuan menguntungkan diri sendiri atau orang lain atau suatu korporasi, yang kedua rumusan ini harus saling terkait satu sama lain. Jadi belum tentu unsur menyalahgunakan kewenangan, kesempatan atau sarana yang ada padanya karena jabatan atau kedudukan dapat dijatuhkan pidana jika sebelumnya yaitu unsur tujuan menguntungkan diri sendiri atau orang lain atau suatu korporasi tidak terbukti.

Unsur perbuatan menyalahgunakan kewenangan, kesempatan atau sarana yang ada padanya karena jabatan atau kedudukan dalam konteks hukum pidana adalah menggunakan kewenangan ataupun kekuasaan, kesempatan, atau sarana yang melekat pada jabatan atau kedudukan yang sedang dijabat atau diduduki oleh pelaku tindak pidana korupsi untuk tujuan selain dari maksud diberikannya kewenangan ataupun kekuasaan, kesempatan, atau sarana tersebut. ${ }^{64}$

Unsur melawan hukum dalam Pasal 2 ayat (1) UUPTPK sebagai bestandeel delict, unsur "menyalahgunakan wewenang dalam Pasal 3 UUPTPK juga sebagai bestandeel delict. Jika unsur penyalahgunaan wewenang tidak terbukti, maka terhadap pegawai negeri atau penyelenggara negara yang diduga melakukan tindak pidana korupsi tidak dapat

\footnotetext{
${ }^{63}$ Pasal 3 UUPTPK

${ }^{64}$ Ermansjah Djaja, Tipologi Tindak Pidana...Op.
} cit., hal. 159 
Media Komunikasi dan Informasi Hukum dan Masyarakat

dikategorikan sebagai menyalahgunakan wewenang.

Pengertian menyalahgunakan
kewenangan dalam hukum pidana
maupun dalam undang-undang pidana
tidak memiliki makna yang memadai.
Berdasarkan teori otonom dari hukum
pidana mempertanyakan apakahada
harmoni dan disharmoni pengertian
yang sama antara hukum pidana,
hukum perdata, dan hukum
administrasi negara. Maksud
disharmoni adalah dalam hal
seseorang memberikan pengertian
dalam undang-undang hukum pidana
dengan isi lain mengenai pengertian
yang sama bunyinya dalam cabang
hukum lain.65

Berdasarkan teori otonom, hukum pidana mempunyai otonom untuk memberikan pengertian yang berbeda dengan pengertian yang terdapat dalam cabang hukum lainnya. Dalam konteks ini jika pengertian menyalahgunakan kewenangan tidak ditemukan secara eksplisit dalam hukum pidana maka hukum pidana dapat menggunakan pengertian dan kata yang sama pada cabang ilmu lainnya. ${ }^{66}$

Bilamana hukum pidana tidak memberikan pengertian mengenai penyalahgunaan wewenang, dan pengertian tersebut hanya terdapat dalam wilayah hukum administrasi negara, maka dengan sendirinya pengertian tersebut mengacu pada pengertian dalam hukum administrasi negara. Pengertian penyalahgunaan wewenang dalam konteks hukum administrasi negara dalam tiga bentuk: ${ }^{67}$

a. Penyalahgunaan wewenang untuk melakukan tindakan-tindakan yang bertentangan dengan kepentingan umum atau untuk menguntungkan kepentingan pribadi, kelompok atau golongan. cit, hal. 426.

${ }^{65}$ Indriyanto Seno Adji, Korupsi Kebijakan...Op.

${ }^{66} \mathrm{Ibid}$., hal. 427.

${ }^{67} \mathrm{lbid} .$, hal. $427-428$ b. Penyalahgunaan wewenang dalam arti tindakan pejabat tersebut ditujukan untuk kepentingan umum, tapi menyimpang dari tujuan kewenangan itu diberikan oleh undang-undang atau peraturan-peraturan tertulis.

c. Penyalahgunaan wewenang dalam arti menyalahgunakan prosedur yang seharusnya dipergunakan untuk mencapai tujuan tertentu, tetapi telah menggunakan prosedur lain agar terlaksana.

Unsur menyalahgunakan kewenangan, kesempatan atau sarana yang ada padanya karena jabatan atau kedudukan dalam Pasal 3 UUPTPK harus tertuju subjek dalik sebagai pejabat atau mempunyai kedudukan di pemerintahan. Sehingga unsur menyalahgunakan kewenangan, kesempatan atau sarana yang ada padanya karena jabatan atau kedudukan dijabat atau diduduki oleh pelaku tindak pidana korupsi untuk tujuan lain dari maksud diberikannya kewenangan, kesempatan, atau sarana tersebut. ${ }^{68}$

Kesempatan adalah peluang atau tersedianya waktu yang cukup untuk melakukan perbuatan tertentu.Orang yang karena memiliki jabatan atau kedudukan dan karena jabatan atau kedudukan itu mempunyai peluang atau waktu untuk melakukan perbuatan-perbuatan yang bertentangan dengan jabatan atau kedudukannya.Jika peluang ini digunakan untuk melakukan perbuatan yang bertentangan dengan tugas pekerjaannya dalam jabatan atau kedudukan yang dimilikinya, maka dalam hal ini telah

68

R. Wiyono, Pembahasan Undang-Undang Pemberantasan Tindak Pidana Korupsi, Sinar Grafika, Jakarta, 2009, hal. 38 . 
Media Komunikasi dan Informasi Hukum dan Masyarakat

terjadi penyalahgunaan kesempatan karena jabatan atau kedudukan. ${ }^{69}$

Sarana adalah perlengkapan atau fasilitas, menyalahgunakan sarana adalah menyalahgunakan fasilitas atau perlengkapan yang ada melekat pada pelaku karena jabatan atau kedudukannya.Unsur menyalahgunakan kewenangan, kesempatan atau sarana yang ada padanya karena jabatan atau kedudukan menunjukkan bahwa antara kewenangan, kesempatan, sarana, dan kedudukan atau jabatan merupakan satu kesatuan yang utuh yang dimiliki oleh pejabat (pegawai negeri) yang melakukan tindak pidana korupsi.Sebab dengan memberikan jabatan atau kedudukan kepada seorang pejabat administrasi maka wewenang, kesempatan, atau sarana dengan sendirinya mengikuti. ${ }^{70}$

Berdasarkan uraian tersebut, menyalahgunakan kewenangan, kesempatan atau sarana hanya berkaitan dengan jabatan atau kedudukan yang melekat pada diri seseorang pegawai negeri yang melakukan tindak pidana korupsi.Selain pegawai negeri atau pejabat termasuk pegawai BUMN maupun BUMD, tidak bisa dikonstruksikan sebagai penyalahgunaan wewenang.Jika terdakwa didakwa dengan Pasal 3 UUPTPK tapi bukan sebagai pegawai negeri, maka dalam hal ini konstruksi hukumnya telah salah dalam memahami esensi penyalahgunaan wewenang dan melawan hukum. ${ }^{71}$

\section{KESIMPULAN}

1. Subjek hukum dalam tindak pidana korupsi ada 2 yaitu : (1) orang yaitu setiap orang maksudnya adalah subjek yang diduga sebagai pelaku korupsi. Jika diperhatikan

\footnotetext{
${ }^{69}$ Mahrus Ali, Op. cit., hal. 101

${ }^{70}$ Ibid., hal. 102.

${ }^{71}$ Ibid.
}

subjek korupsi dalam Pasal 1 UUPTPK meliputi setiap orang, pegawai negeri, penyelenggara negara, dan korporasi (badan hukum dan non badan hukum). Maksud setiap orang dalam UUPTPK adalah termasuk siapa saja, baik kedudukannya sebagai pegawai negeri atau penyelenggara negara, akan tetapi unsur setiap orang yang didefenisikan di dalam Pasal 1 angka 3 hanya menentukan untuk orang perseorangan atau korporasi. (2) Korporasi sebagai Pelaku dan yang dapat dimintai pertanggungjawaban pidana atas perbuatan korupsi yang dilakukan pengurusnya.

2. Melawan hukum (wederrechtelijk) menunjukkan sifat yang tidak sah dari suatu tindakan (vide: Pasal 167 ayat 1, Pasal 179, Pasal 180, dan Pasal 190 KUHP), dan sifat tidak sah dari suatu maksud (vide: Pasal 328, Pasal 339, Pasal 362, dan Pasal 389 KUHP). Melawan hukum merupakan salah satu unsur tindak pidana di dalam Pasal 2 ayat (1) UUPTPK, yaitu sifat melawan hukum khusus. Perbuatan yang masuk kategori melawan hukum secara formil yaitu melakukan sesuatu terbatas pada larangan undangundang.Sedangkan yang dimaksud dengan melawan hukum secara materil adalah melakukan sesuatu yang dilarang dalam undang-undang maupun berdasarkan asas hukum yang tidak tertulis.Jika dalam suatu pasal secara nyata terdapat unsur melawan hukum, maka penuntut umum harus membuktikannya, jika unsur tersebut tidak terbukti maka putusannya bebas (vrijspraak). Jika unsur melawan hukum tidak secara tegas merupakan unsur dari suatu tindak pidana maka tidak terbuktinya 
Media Komunikasi dan Informasi Hukum dan Masyarakat

unsur tersebut menyebabkan putusannya lepas dari segala tuntutan hukum (onslag van rechtverfolging).

3. Menyalahgunakan diartikan dalam konteks hukum pidana adanya hak atau kekuasaan yang dilakukan tidak sebagaimana mestinya seperti telah menguntungkan orang lain, anak, cucu, keluarga, atau kroni-kroninya. Menyalahgunakan kesempatan atau waktu pada diri pelaku sehubungan dengan kedudukan atau jabatan. Menyalahgunakan saran berarti menyalahgunakan perlengkapan atau fasilitas yang ada melekat pada diri pelaku karena jabatan atau kedudukan.

Penyalahgunaan kewenangan pada prinsipnya merupakan wilayahnya hukum administrasi negara yang tidak bisa dipidanakan melainkan pelanggaranadministrasi. Unsur menyalah gunakan kewenangan, kesempatan atau sarana yang ada padanya karena jabatan atau kedudukan ternyata dapat ditemukan di dalam Pasal 3 UUPTPK.Unsur ini dikenal dalam hukum pidana korupsi yaitu unsur menyalahgunakan kewenangan, kesempatan atau sarana yang ada padanya karena jabatan atau kedudukan. Yang membedakan unsur menyalahgunakan kewenangan, kesempatan atau sarana yang ada padanya karena jabatan atau kedudukan dapat dipidana dibandingkan dengan penyalahgunaan wewenang dalam hukum administrasi hanya merupakan pelanggaran administrasi. Ternyata jika diperhatikan rumusan Pasal 3 UUPTPK, unsur menyalahgunakan kewenangan, kesempatan atau sarana yang ada padanya karena jabatan atau kedudukan, tidaklah berdiri sendiri, tapi ada kaitannya dengan sifat dan perilaku koruptif yakni adanya unsur tujuan menguntungkan diri sendiri atau orang lain atau suatu korporasi.

\section{DAFTAR PUSTAKA}

A.Zainal Abidin, Hukum Pidana I, Sinar Grafika, Jakarta, 2007.

Adami Chazawi, Hukum Pidana Materil dan Formil Korupsi di Indonesia, Bayumedia Publishing, Malang, 2005.

Andi Hamzah, Pemberantasan Korupsi Melalui Hukum Pidana Nasional dan Internasional, RajaGrafindo Persada, Jakarta, 2004.

Chairul Huda, Dari Tiada Pidana Tanpa Kesalahan Menuju Tiada Pertanggungjawaban Pidana Tanpa Kesalahan, Jakarta, Kencana, 2006.

Darwin Prints, Pemberantasan Tindak Pidana Korupsi, Citra Adtya Bakti, Bandung, 2002.

Erman Rajagukguk, Pengertian Keuangan Negara dan Kerugian Negara, Makalah yang Disampaikan pada Seminar Pengertian, Keuangan Negara Dalam Tindak Pidana Korupsi, Jakarta, Tanggal 26 Juli 2006.

EY Kanter,. \& SR. Sianturi, Asas-asas Hukum Pidana Di Indonesia Dan Penerapanya, Storia Jakarta, Jakarta, 2002.

J.M. van Bemmelen, Hukum Pidana I: Hukum Pidana Material Bagian Umum, Diterjemahkan oleh Hasan, Bina Cipta, tanpa tempat 1984.

Jan Remmelink, Hukum Pidana, Komentar Atas Pasal-Pasal Terpenting dari Kitab Undang-Undang Hukum Pidana Belanda dan Padanannya Dalam Kitab Undang-Undang Hukum Pidana Indonesia, Gramedia Pustaka Utama, Jakarta, 2003.

Mahrus Ali, Hukum Pidana Korupsi, UII Press, Yogyakarta 2016. 
Media Komunikasi dan Informasi Hukum dan Masyarakat

Moeljatno, Asas-Asas Hukum Pidana,: Rineka Cipta, Jakarta, 2008.

Nur Basuki Minarmo, Penyalahgunaan Wewenang dan Tindak Pidana Korupsi Dalam Pengelolaan Keuangan Daerah, Leksbang Mediatama, Yogyakarta, 2009.

P.A.F Lamintang,. Dasar-Dasar Hukum Pidana Indonesia, Sinar Baru, Bandung 1984.

R. Wiyono, Pembahasan Undang-Undang Pemberantasan Tindak Pidana Korupsi, Sinar Grafika, Jakarta 2009.

Roeslan Soleh, Sifat Melawan Hukum Dari Perbuatan Pidana, Aksara Baru, Jakarta, 1987.

SR. Sianturi, Tindak Pidana di KUH Pidana, Alumni AHM-PTHM, Jakarta, 1983.

Tongat, Dasar-Dasar Hukum Pidana Indonesia Dalam Perspektif Pembaharuan, UMM Press, Malang. 2008. 